\title{
Magnetic Properties of $\mathrm{CuO}$ - CuS Nanocomposites
}

\author{
R. Veeralekshmi ${ }^{1}$, K.U. Madhu ${ }^{2}$ \\ ${ }^{1,2}$ Physics Research Centre, S. T. Hindu College, Nagercoil - 629 002, India \\ Affiliated to Manonmaniam Sundaranar University, Abishekapatti, Tirunelveli-627012, India \\ *Corresponding Author: meetvlr89@gmail.com, (Research Scholar, Reg.No: 11998) Tel.: 04652-254158
}

Available online at: www.isroset.org

Received: 08/Dec/2018, Accepted: 19/Dec/2018, Online: 31/Dec/2018

\begin{abstract}
In this study, nanocomposites of $\mathrm{CuS}_{\mathrm{x}} \mathrm{O}_{(1-\mathrm{x})}$ (with $\mathrm{x}$ values $0.0,0.2,0.4,0.5,0.6,0.8,1.0$ ) was prepared by simple microwave assisted solvothermal method using distilled water as solvent. The as-prepared samples are annealed at $200{ }^{\circ} \mathrm{C}$. They were characterized using powder X-ray diffraction analysis (PXRD) and vibrating sample magnetometer (VSM) measurements. The PXRD results demonstrate that the end members of $\operatorname{CuS}_{\mathrm{x}} \mathrm{O}_{(1-\mathrm{x})}$ nanocomposites (for $\mathrm{x}=1.0$ and 0.0 ) has hexagonal structure of $\mathrm{CuS}$ and monoclinic structure of $\mathrm{CuO}$ respectively. The middle composition of $\mathrm{CuS}_{\mathrm{x}} \mathrm{O}_{(1-\mathrm{x})}$ nanocomposites (for $\mathrm{x}=0.8,0.6,0.5,0.4,0.2$ ) has mixed phase of hexagonal and monoclinic structures, which confirms the formation of $\mathrm{CuS}_{\mathrm{x}} \mathrm{O}_{(1-\mathrm{x})}$ nanocomposites. The average crystallite size was calculated from Scherrer equation. The VSM measurements of all the proposed samples indicate the paramagnetic nature. The results obtained were reported and discussed herewith.
\end{abstract}

Keywords - Solvothermal, paramagnetism, nanocomposites, PXRD analysis, VSM measurements.

\section{INTRODUCTION}

Nanomaterials have become important owing to their small size and large surface area. They exhibit unique properties which are not seen in bulk materials. They are widely used in photovoltaic cells, optical and biological sensors, conductive materials and coating formulations. Among these materials nanoscale transition metal chalcogenides have attracted a great deal of research interest in recent years. Copper oxide and copper sulphide has received much attention for the applications in the fields ranging from energy conversion and storage, electronics, sensors and environmental science $[1,2]$. It is still a challenge to develop a simple, rapid, eco-friendly, easy to control and energyefficient method for a large scale preparation of $\mathrm{CuO}-\mathrm{CuS}$ nanocomposites.

Various methods are being adapted to the synthesis of $\mathrm{CuO}$ and $\mathrm{CuS}$ nanoparticles such as sol-gel [3], solid state reaction [4], precipitation [5], sonochemical [6], plasma [7] and reflux condensation [8] method. Among these methods, microwave assisted solvothermal technique is a simple, rapid and versatile method for the synthesis of $\mathrm{CuO}-\mathrm{CuS}$ nanocomposites. This paper deals with the preparation of $\mathrm{CuS}_{\mathrm{x}} \mathrm{O}_{(1-\mathrm{x})}$ nanocompoites using simple microwave assisted solvothermal method and were characterized by PXRD and

VSM analysis. The results obtained were reported and discussed. This article is organized as follows: Section I gives the introduction about nanomaterials. Section II explains the methodology and characterization of copper oxide - copper sulphide nanocomposites. The results and discussion of the related work are discussed in section III and in the last section IV the conclusions of the research work are given.

\section{MATERIALS AND METHODS}

Analytical Reagent (AR) grade copper acetate, urea, thiourea are the precursors and doubly distilled water is the solvent used for the preparation of $\mathrm{CuS}_{\mathrm{x}} \mathrm{O}_{(1-\mathrm{x})}$ (with $\mathrm{x}$ values $0.0,0.2,0.4,0.5,0.6,0.8,1.0)$ nanocomposites. $\mathrm{CuS}_{\mathrm{x}} \mathrm{O}_{(1-\mathrm{x})}$ (with $\mathrm{x}$ values $0.0, \quad 0.2, \quad 0.4, \quad 0.5, \quad 0.6, \quad 0.8, \quad 1.0$ ) 
nanocomposites. For the preparation of $\mathrm{CuS}_{\mathrm{x}} \mathrm{O}_{(1-\mathrm{x})}$ nanocomposites (for $\mathrm{x}=0.2,0.4,0.5,0.6,0.8$ ), copper acetate, thiourea and urea were taken in 1:3 molecular ratio and dissolved separately in doubly distilled water using a magnetic stirrer. Now the solution was kept in a domestic microwave oven (Frequency $=2.45 \mathrm{GHz}$ and power $=$ $800 \mathrm{~W})$. Microwave irradiation was carried out till the solvent was completely get evaporated. The colloidal precipitate formed was then cooled and product was washed several time with doubly distilled water and then with acetone to remove the organic impurities present, if any. The sample was then filtered, dried and collected as yield. Similar procedure were carried out for the two end members $\mathrm{CuO}$ and $\mathrm{CuS}$ nanoparticles. For the preparation of $\mathrm{CuO}$ (for $\mathrm{x}=0$ ) by eliminating thiourea and for $\mathrm{CuS}$ (for $\mathrm{x}=1$ ) for eliminating urea from the precursors used for the synthesis of $\mathrm{CuS}_{\mathrm{x}} \mathrm{O}_{(1-\mathrm{x})}$ nanocomposites (for $\mathrm{x}=0.2,0.4$, $0.5,0.6,0.8)$. In order to improve ordering all the prepared samples were annealed at $200{ }^{\circ} \mathrm{C}$ for 1 hour.

The annealed samples are used for the characterization studies. Using an automated X-ray powder diffractometer with monochromated $\mathrm{CuK}_{\alpha}$ radiation $(\lambda=1.5406 \AA)$ the $\mathrm{x}$ ray powder diffraction data were collected for all the 7 samples and they were compared with the literature for the identification of the sample and the VSM measurements were used to characterize the samples magnetically.

\section{RESULTS AND DISCUSSION}

\section{PXRD analysis}

Figure 1 shows the powder diffraction pattern of $\mathrm{CuS}_{\mathrm{x}} \mathrm{O}_{(1-\mathrm{x})}$ nanocomposites (for $\mathrm{x}=0.0,0.2,0.4,0.5,0.6,0.8,1.0$ ). The diffraction peaks obtained in the spectra corresponding to the $\mathrm{x}$ values $(0.0$ and 1.0$)$ matched more appropriately with the monoclinic phase for copper oxide [9] (JCPDS Card NO: 89-2531) and hexagonal phase of copper sulphide [10] (JCPDS Card NO: 78-2391). The diffraction peaks obtained in the spectra corresponding to the $\mathrm{x}$ values $(0.2,0.4,0.5$, 0.6 , and 0.8 ) contain both copper sulphide and copper oxide phases. The broadening of peaks in the PXRD pattern indicates the nanocrystalline nature of the proposed samples. The average grain size of the samples was found by using Scherrer equation [11] and it was found to as decreasing concentration of oxygen sharpens the diffraction peaks, which in turn increases the crystallite size. When value of $x$ decreases from 1 to 0 , the intensity of $\mathrm{CuS}$ peak get reduced and it produces some new diffraction peaks which confirms that the formation of $\mathrm{CuS}_{\mathrm{x}} \mathrm{O}_{(1-\mathrm{x})}$ nanocomposites. The obtained average grain size was found as $19.44-36.96 \mathrm{~nm}$.

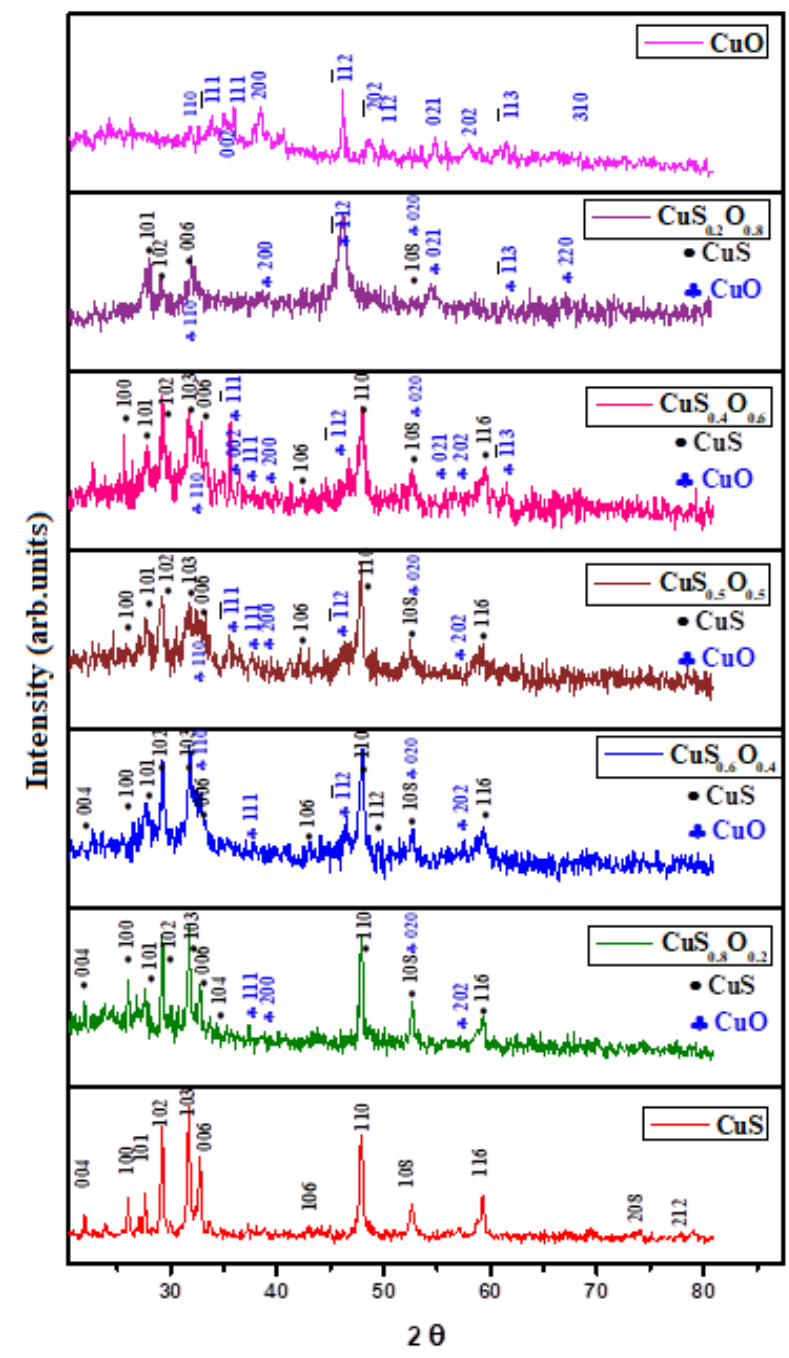

Figure 1. PXRD pattern of $\mathrm{CuS}_{\mathrm{x}} \mathrm{O}_{(1-\mathrm{x})}$ nanocomposites

VSM measurements

The M-H behaviour of the samples was recorded at room temperature using vibration sample magnetometer. Figures 2 -8 shows the plots of the magnetization versus applied field (between $-15000 \mathrm{G}$ and $+15000 \mathrm{G}$ ) of the $\mathrm{CuS}_{\mathrm{x}} \mathrm{O}_{(1-\mathrm{x})}$ nanocomposites. The hysteresis loops showed the change of magnetization with applied field. A narrow hysteresis loop was observed for all the proposed samples. The obtained hysteresis loops confirms the paramagnetic nature of the proposed samples. For paramagnetism the relation between $\mathrm{M}$ and $\mathrm{H}$ is linear and the obtained coercivity and remanent magnetization values, also exhibits paramagnetic behaviour [12] of pure $\mathrm{CuS}_{\mathrm{x}} \mathrm{O}_{(1-\mathrm{x})}$ nanocomposites considered in the present study. 


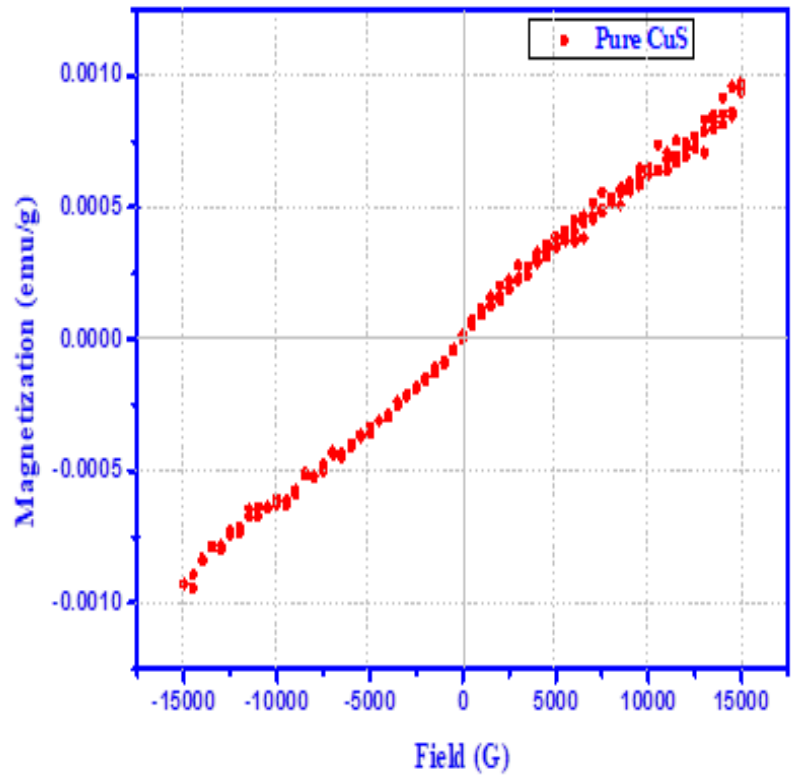

Figure 2. M-H plots for $\mathrm{CuS}$ nanoparticles

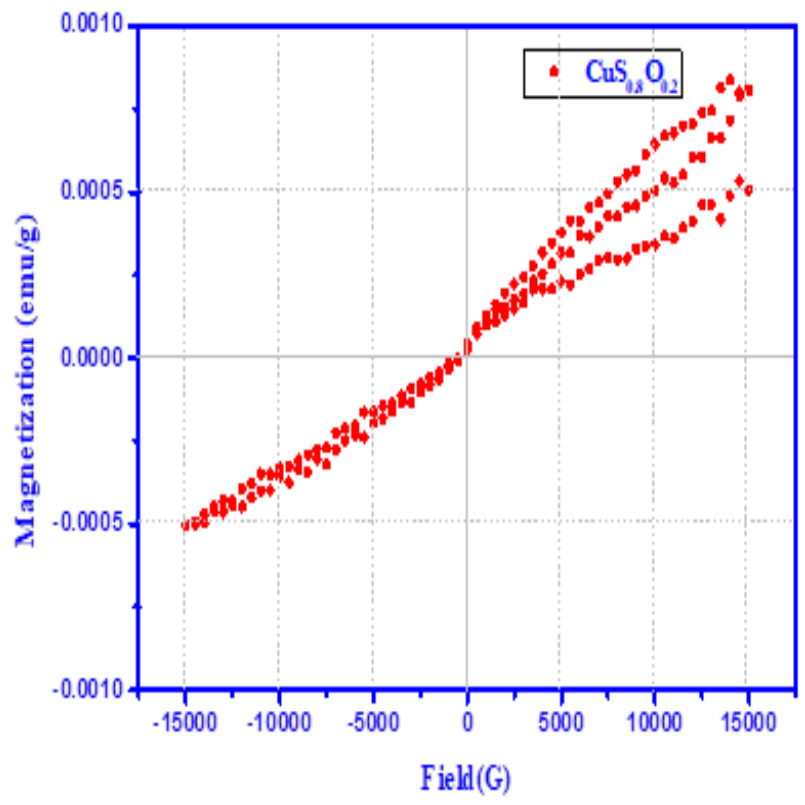

Figure 3. $\mathrm{M}-\mathrm{H}$ plots for $\mathrm{CuS}_{0.8} \mathrm{O}_{0.2}$ nanocomposite

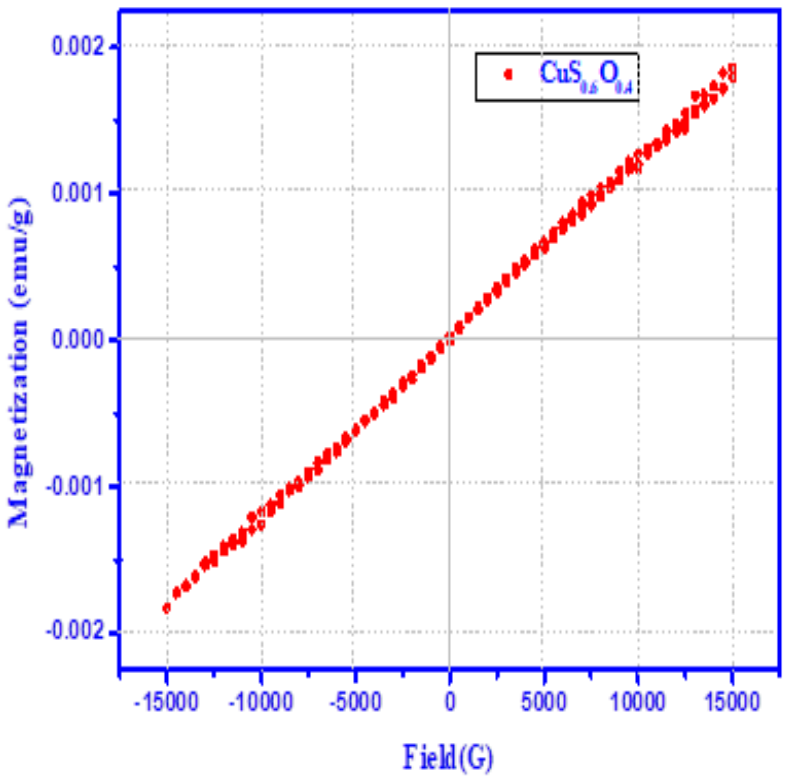

Figure 4. M-H plots for $\mathrm{CuS}_{0.6} \mathrm{O}_{0.4}$ nanocomposite

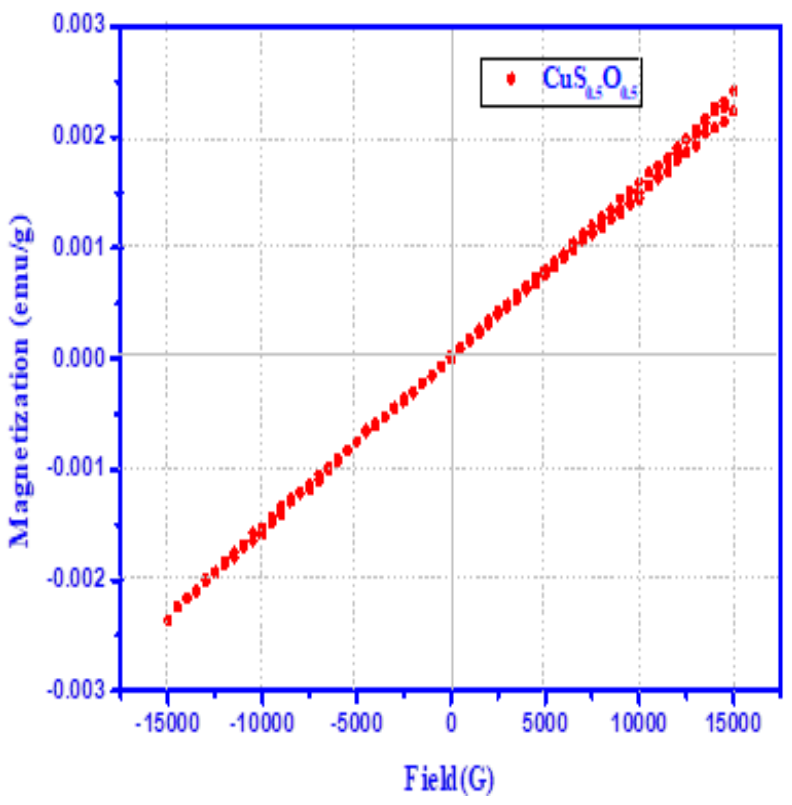

Figure 5. M-H plots for $\mathrm{CuS}_{0.5} \mathrm{O}_{0.5}$ nanocomposite 


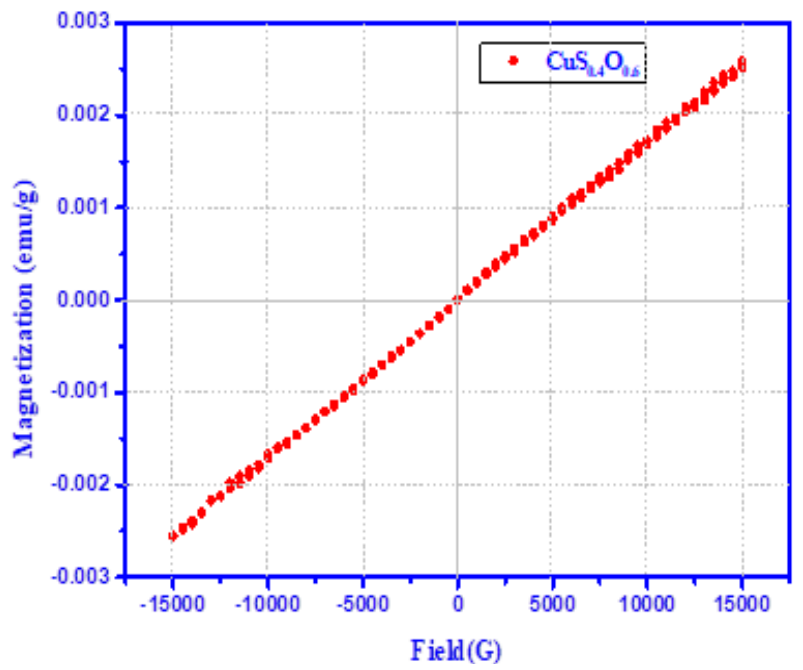

Figure 6. $\mathrm{M}-\mathrm{H}$ plots for $\mathrm{CuS}_{0.4} \mathrm{O}_{0.6}$ nanocomposite

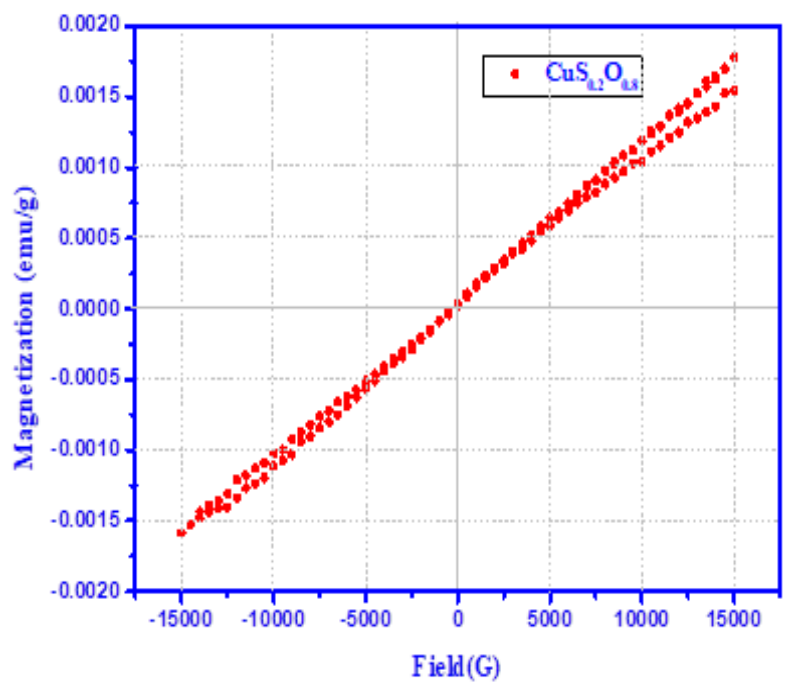

Figure 7. M-H plots for $\mathrm{CuS}_{0.2} \mathrm{O}_{0.8}$ nanocomposite

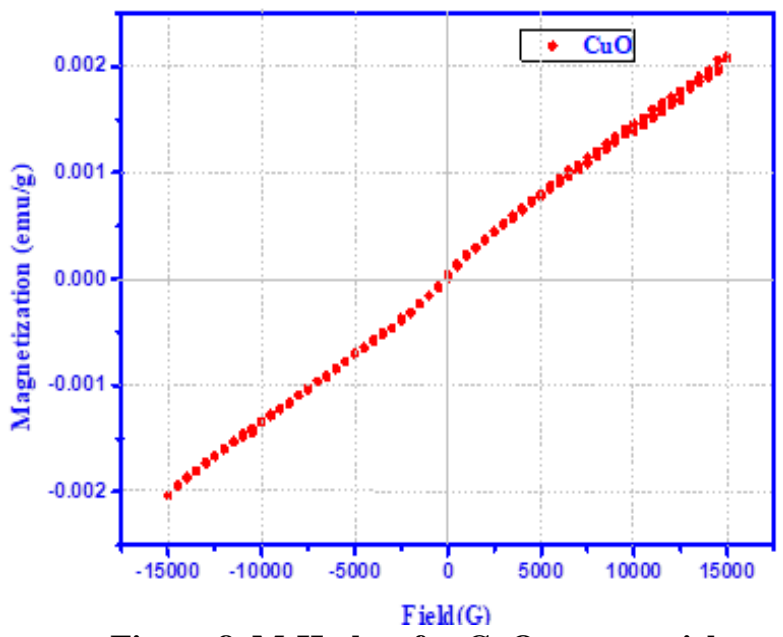

Figure 8. $\mathrm{M}-\mathrm{H}$ plots for $\mathrm{CuO}$ nanoparticles
Table 1 shows the summery of saturated magnetization $\left(\mathrm{M}_{\mathrm{s}}\right)$, remanent magnetization $\left(\mathrm{M}_{\mathrm{r}}\right)$ coercivity $\left(\mathrm{H}_{\mathrm{c}}\right)$ and Squareness ratio $\left(\mathrm{M}_{\mathrm{r}} / \mathrm{M}_{\mathrm{s}}\right)$ data (observed from VSM) of $\mathrm{CuS}_{\mathrm{x}} \mathrm{O}_{(1-\mathrm{x})}$ nanocomposites. The obtained data reveals that the coercivity and remanent magnetization for $\mathrm{CuS}_{0.6} \mathrm{O}_{0.4}$ nanocomposite is maximum and the value of coercivity and remanent magnetization is minimum for $\mathrm{CuS}_{0.4} \mathrm{O}_{0.6}$ nanocomposite. The squareness ratio is minimum for $\mathrm{CuS}_{0.4} \mathrm{O}_{0.6}$ naocomposite. While the squareness ratio of $\mathrm{CuS}_{0.8} \mathrm{O}_{0.2}$ nanocomposite is maximum. It also indicates that the increase in oxygen concentration increases the saturated magnetization except low concentration of oxygen $\left(\mathrm{CuS}_{0.8} \mathrm{O}_{0.2}\right)$ and high concentration of oxygen $\left(\mathrm{CuS}_{0.2} \mathrm{O}_{0.8}\right)$. Low saturated magnetization value was observed for $\mathrm{CuS}_{0.8} \mathrm{O}_{0.2}$ nanocomposites and high saturated magnetization value was observed for $\mathrm{CuS}_{0.4} \mathrm{O}_{0.6}$ nanocomposites. The magnetic response of the material shows that the proposed samples can be used as interesting magnetic material.

Table 1. Summery of saturated magnetization (Ms), remanent magnetization $\left(M_{r}\right)$ coercivity $\left(H_{c}\right)$ and Squareness ratio (Mr/Ms) data (observed from VSM) of $\mathrm{CuS}_{\mathrm{x}} \mathrm{O}_{(1-\mathrm{x})}$ nanocomposites

\begin{tabular}{|c|c|c|c|c|}
\hline System & $\begin{array}{c}\text { Coercivi } \\
\text { ty } \\
\mathbf{H}_{\mathrm{c}}(\mathbf{G})\end{array}$ & $\begin{array}{c}\text { Remanent } \\
\text { magnetizati } \\
\text { on } M_{r} \\
\left(\times 10^{-6} \mathrm{emu}\right)\end{array}$ & $\begin{array}{c}\text { Saturated } \\
\text { magnetizati } \\
\text { on } \\
M_{\mathrm{s}} \\
\left(\mathbf{x 1 0}^{-3} \mathrm{emu}\right)\end{array}$ & $\begin{array}{c}\text { Squarene } \\
\text { ss ratio } \\
\left(\mathbf{M}_{\mathbf{r}} / \mathbf{M}_{\mathrm{s}}\right) \\
\left(\mathbf{x 1 0 ^ { - 3 }}\right)\end{array}$ \\
\hline $\mathrm{CuS}$ & 32.466 & 4.739 & 0.959 & 4.941 \\
\hline $\begin{array}{l}\mathrm{CuS}_{0.8} \mathrm{O} \\
0.2\end{array}$ & 31.491 & 7.733 & 0.690 & 11.207 \\
\hline $\begin{array}{l}\mathrm{CuS}_{0.6} \mathrm{O} \\
0.4\end{array}$ & 120.58 & 17.891 & 1.840 & 9.723 \\
\hline $\begin{array}{l}\mathrm{CuS}_{0.5} \mathrm{O} \\
0.5\end{array}$ & 81.824 & 14.987 & 2.391 & 6.268 \\
\hline $\begin{array}{l}\mathrm{CuS}_{0.4} \mathrm{O} \\
0.6\end{array}$ & 18.589 & 4.496 & 2.570 & 1.749 \\
\hline $\begin{array}{l}\mathrm{CuS}_{0.2} \mathrm{O} \\
0.8\end{array}$ & 23.459 & 4.841 & 1.683 & 2.876 \\
\hline $\mathrm{CuO}$ & 75.979 & 17.823 & 2.062 & 8.643 \\
\hline
\end{tabular}




\section{CONCLUSION}

$\mathrm{CuS}_{\mathrm{x}} \mathrm{O}_{(1-\mathrm{x})}$ (with $\mathrm{x}$ values $0.0,0.2,0.4,0.5,0.6,0.8,1.0$ ) nanocomposites were synthesized using simple microwave assisted solvothermal method. The PXRD measurements confirms the proposed samples are $\mathrm{CuS}_{\mathrm{x}} \mathrm{O}_{(1-\mathrm{x})}$ nanocomposites. The average particle size was calculated by Scherrer relation and it was found to be $19.44-36.96 \mathrm{~nm}$. The magnetic property of the proposed samples were characterized by VSM measurements at room temperature. The M-H plots of the proposed samples are found to have a paramagnetic nature which is revealed by the narrow magnetic hysteresis behaviour shown by the samples. The magnetic response of the material shows that the proposed samples can be considered as an interesting magnetic material and also, it could be understood that the nanocomposites prepared are expected to be useful in solar cells, electro-optical devices, etc.

\section{REFERENCES}

[1]. S. Goel, F. Chen, W. Cai, "Synthesis and Biomedical Applications of Copper Sulfide Nanoparticles: From Sensors to Theranostics", Small, Vol. 10, Issue. 4, pp. 631-645, 2013.

[2]. A. Gogos, B. Thalmann, A. Voegelin, R. Kaegi, "Sulfidation kinetics of copper oxide nanoparticles" Environmental Science: Nano, Vol. 4, Issue. 8, pp.1733-1741, 2017.

[3]. Zohra N. Kayania, Yasmin Alia, Faiza Kirana, Iffat Batoola, Mehak Z. Butta , Maryam Umera, Saira Riazb, Shahzad Naseem., "Fabrication of copper oxide nanoparticles by sol-gel route", Materials Today: Proceedings., Vol. 2, pp. 5446 - 5449, 2015.

[4]. N. Kumaresan, K. Ramamurthi, S. Mathuri, Maria Angelin Sinthiya, T. Manimozhi, Mahesh Mudaliar Margoni, R. Rameshbabu, "Solid State Synthesis Of Cuo Nanoparticles For Photo Catalytic Application", International Conference on Nanoscience and Nanotechnology, Vol. 7, Issue. 3, pp. 1598-1602, 2015.

[5]. N. Malviya, G. Carpenter, N. Oswal, N. Gupta, "Synthesis and Characterization of $\mathrm{CuO}$ Nano particles Using Precipitation Method", AIP Conf. Proc., Vol. 1665, 050038-1-050038-3, 2015.

[6]. K. Krishnamoorthy K, G. K Veerasubramani, S. Radhakrishnan, S.J. Kim SJ., "Preparation of copper sulfide nanoparticles by sonochemical method and study on their electrochemical properties", J. Nanosci. Nanotechnology, Vol. 15, Issue. 6, pp. $4409-4413,2015$.

[7]. Zhypargul Abdullaeva, Emil Omurzak, Tsutomu Mashimo, "Synthesis of copper sulphide nanoparticles by pulsed plasma in liquid method", Int. J. Che. Mol. Nuc. Mat. Metall. Eng, Vol. 7, no. 6, pp. $422-425,2013$.

[8]. K. Mageshwari, S.S Mali, T. Hemalatha, R. Sathyamoorthy, P.S Patil, "Low temperature growth of $\mathrm{CuS}$ nanoparticles by reflux condensation method", Progress in Solid State Chemistry, Vol. 39, pp. 108-113, 2011.

[9]. A.M. Awwad, B.A. Albiss, N. Salem, "Antibacterial Activity of synthesized Copper Oxide Nanoparticles using Malva sylvestris Leaf Extract”, SMU Medical Journal, Vol. 2, pp. 91 - 101, 2015.

[10]. S.A. Hussein, A. Hmeed, A.S. Hadi, "Study of the structural and optical properties of thin films copper sulfide $(\mathrm{CuS})$ prepared by chemical spray pyrolysis", IOSR Journal of Sports and Physical Education, Vol. 3, pp. 46 - 50, 2016.
[12]. K. Kannaki, P.S. Ramesh, D. Geetha, "Hydrothermal synthesis of $\mathrm{CuO}$ nanostructure and their characterizations", International Journal of Scientific \& Engineering Research, vol 3, no. 9, pp. 1 4, 2012.

[13]. M. Annie Freeda, C.K. Mahadevan, 2017, "Synthesis at room temperature and characterization of pure and $\mathrm{Mn}^{2+}$ doped $\mathrm{CuS}$ nanocrystals", Journal of Alloys and Compounds, pp. 1 - 5, 2017. 